\title{
РОЛЬ ПОЛЬСЬКИХ ЗАПОЗИЧЕНЬ У ФОРМУВАННІ МОВНОЇ КАРТИНИ СВІТУ УКРАЇНЦІВ (НА МАТЕРІАЛІ УКРАЇНСЬКИХ ПИСЕМНИХ ПАМ'ЯТОК ХVI-XVII СТ.)
}

\author{
СВІТЛАНА ГРИЦЕНКО \\ Київський національний університет імені Тараса Шевченка, Київ - Україна \\ ROLA POLSKICH ZAPOŻYCZEŃ W KSZTAŁTOWANIU \\ JEZZYKOWEGO OBRAZU ŚWIATA UKRAIŃCÓW \\ (NA PODSTAWIE UKRAIŃSKICH \\ ZABYTKÓW PISANYCH XVI — XVII WIEKU)
}

SWITŁANA HRYCENKO

Kijowski Uniwersytet Narodowy im. Tarasa Szewczenki, Kijów — Ukraina

STRESZCZENIE. Wzmożone zainteresowanie badaczy zagadnieniem polskich zapożyczeń leksykalnych oraz ich adaptacji do systemu języka-odbiorcy jest w znacznym stopniu uwarunkowane dużą liczbą takich zapożyczeń w ukraińskich zabytkach pisanych XVIXVII w. Przeanalizowane ukraińskie zabytki pisane wskazanego okresu demonstrują ideograficzną różnoplanowość polskojęzycznych zapożyczeń leksykalnych, umożliwiających modelowanie struktury językowego obrazu świata. Ważnym aspektem powyższej analizy jest ocena roli omawianych zapożyczeń: czy poszerzają one strukturę pojęciową języka, czy raczej poszerzają zasoby wyrażania obecnych w języku, lecz wcześniej już ukształtowanych pojęć.

\author{
THE ROLE OF POLISH BORROWINGS IN SHAPING \\ THE UKRAINIANS' LANGUAGE MAP OF THE WORLD \\ (ON THE MATERIAL OF UKRAINIAN \\ LITERATURE SOURCES OF XVI-XVII CENTURIES)
}

\section{SVITLANA GRYTSENKO \\ Taras Shevchenko Kyiv National University, Kyiv — Ukraine}

\begin{abstract}
Linguists' great interest to the problem of borrowing lexical polonisms and their adaptation into the system of a language-recipient is caused by their wide use in Ukrainian literature of the XVI-XVII ${ }^{\text {th }}$ centuries. Discovered Ukrainian sources of the researched period demonstrate ideographic divercity of Polish lexical borrowings that allows modeling the structure of language mapping of the world, solving the problem whether borrowings enrich the structure of language concepts or just vary the means of conceptual expressions that were formed in the past and already exist in the language.
\end{abstract}

$\mathrm{B}$ історії України період XVI - XVII ст. - епоха енергійного культурнопросвітницького руху, розквіту науки й літератури. На цей час припадає перше культурне відродження України, що, „розбудило громадську енергію, (...) викликало нові пориви національної солідарності, викресало нові колективні форми громадської кооперації, нові методи освіти й культурного 
виховання" в Україні реформаційних рухів як сприйнятих із Заходу й частково зі Сходу, так і витворених на місцевій основі. На думку Я. Ісаєвича, існують підстави розмірковувати про формування того типу суспільного руху, що був властивий „північному ренесансові”, й тієї культури, що виникла на цій основі².

Найкращим лакмусом усіх змін, що відбувалися в українському суспільстві, стала мова. Як стверджує В. Німчук, мовна ситуація в досліджуваний період в Україні була „найскомплікованіша у Свропі (якщо не в усьому світі)”’, оскільки активно розвивалися й застосовувалися різні мови, що належали до відмінних мовних систем, мали різну структуру й відрізнялися як походженням, так і характером використання; це були українська (руська), церковнослов'янська (слов'янська), грецька, латинська, гебрайська та ідиш, вірменська, турецька, кипчацько-татарська, польська, німецька, угорська, італійська, французька та ін. ${ }^{4}$.

Невичерпним джерелом збагачення староукраїнської мови стали лексичні запозичення, що вносили суттєві корективи у формування МКС українців досліджуваного періоду. Лінгвісти роблять спроби осмислити складний і протяжний у часі, а тому й мінливий процес запозичення, його етапи та риси, виокремлюючи при цьому свій предмет дослідження як самодостатній.

Метою цієї розвідки є аналіз польських запозичень, виявлених в українських писемних пам'ятках к. XVI - XVII ст., та з'ясування їхньої ролі у формуванні МКС українців. Зауважимо, що в історії української і польської мов їхні контакти в період XVI - XVII ст. мали важливе значення: вони були обопільно інтенсивними й вплинули на розвиток обох мов ${ }^{5}$, зокрема вплив польської мови на сучасну українську мову досліжувала Д. Будняк ; окремий хронологічний зріз побутування польської мови в Україні, а саме XVII ст., вивчала О. Лазаренко ; лексичні полонізми в актовій мові були предметом наукового інтересу М. Худаша ${ }^{8}$.

Закцентуємо увагу на важливих аспектах дослідження результатів мовного контактування - запозиченнях: проаналізуємо їх репертуар, шляхи переміщення в староукраїнську мову, час переймання, адаптацію до системи мовиреципієнта та їх функціонування в сучасній українській мові.

Одним із напрямків дослідження запозичень $є$ створення їх тематичної класифікації, виділення тематичних груп лексики. Саме через тематичну та се-

${ }^{1}$ М. Груш е в с ь к и й, Історія Украӥни-Руси в 7 m., Київ 1991, т. 6, с. 113.

2 Я. І с а $є$ в ич, Украӥнська культура на переломі (друга половина XVI - перша половина XVII cm.). Культурно-начіональне відродження. Загальна характеристика періоду, [в:] Історія української культури в 2 т., Київ 2001, т. 2, с. 482-483.

${ }^{3}$ В. В. Н ім ч у к, Конфесійне питання і украӥнська мова кіния XVI- початку XVII століть, [в:] Берестейська унія і українська культура ХVII століття, Львів 1996, с. 1.

${ }^{4} \mathrm{O}$. Ку п ч и н с ь к и й , Украӥнська церква і питання украӥнської (руської) народно-розмовної мови у другій половині XVI-XVII століттях, [в:] „Warszawskie zeszyty ukrainoznawcze” Warszawa 1997, 4-5, с. 205.

${ }^{5}$ И. И. Пер в о ль ф, Славянская взаимность от древнейших времен до XVIII в., СПб. 1874; Р. Р и х ард т, Польские заимствованные слова в украинском языке, Киев 1957; В. М. Р ус ан і в ський, Польська ділова мова XVI - XVII cm. як джерело вивчення їі історичних взаємин з украӥнською, [в:] Славістичний збірник, Київ 1963, с. 86-97.

${ }^{6}$ Д. Будн я к, Полонизмы в современном украинском литературном языке, Автореф. дис. канд. філол. наук, Київ 1991.

${ }^{7}$ О.М. Л а з а р е н ко , Особливості функиіонування польськоїмови в Україні у ХVII столітті (на матеріалі творів Лазаря Барановича), Автореф. дис. канд. філол. наук, Київ 2005.

${ }_{8}$ М. Л. Худа ш, Лексика українських ділових пам'яток кіния XVI - початку XVII cm. (на матеріалах Львівського Ставропігійського братства), Київ 1961. 
мантичну класифікації можна наблизитися до розв'язання питання про роль запозичень: чи розширюють запозичення понятійну структуру мови, чи лише розширюють засоби вираження наявних у мові сформованих давніше понять. Водночас через класифікацію лексики стає можливим моделювання структури МКС. Р. Гжегорчикова зауважує, що „незаперечно найважливішими [для 3'ясування мовного образу світу. - С. Г.] є явища лексичні, а найбільше групи словникового складу, що становлять своєрідний класифікатор світу"9. У принципах класифікації лексики на тематичні групи, способах встановлення взаємозв'язків між ними відбивається певне уявлення про зовнішній світ, створюється своєрідна МКС. Ф. Дорнзайф наголошував, що під час класифікації лексичного матеріалу „необхідно виходити не з окремих слів, щоб визначити їх значення, а з речей, понять; цей шлях саме й означає вивчення словесної оболонки для думки"10.

Методом суцільного розписування староукраїнських пам'яток кін. XVI XVII ст. та внаслідок опрацювання лексикографічних джерел було досліджено 17 тематичних груп лексики, в яких виявлено 975 лексичних запозичень із 28 мов, серед яких 357 полонізмів (див.: Табл. 1).

Таблиця $1 .{ }^{11}$

\begin{tabular}{|c|c|c|c|c|c|c|c|c|c|c|c|c|c|c|c|c|c|}
\hline Мова & $\mathbf{1}$ & $\mathbf{2}$ & $\mathbf{3}$ & $\mathbf{4}$ & $\mathbf{5}$ & $\mathbf{6}$ & $\mathbf{7}$ & $\mathbf{8}$ & $\mathbf{9}$ & $\mathbf{1 0}$ & $\mathbf{1 1}$ & $\mathbf{1 2}$ & $\mathbf{1 3}$ & $\mathbf{1 4}$ & $\mathbf{1 5}$ & $\mathbf{1 6}$ & $\mathbf{1 7}$ \\
\hline пол. & 108 & 70 & 17 & - & 5 & 10 & 2 & 4 & 2 & 5 & 8 & 15 & 52 & 1 & 10 & 35 & 13 \\
\hline чес. & - & 2 & - & - & - & - & - & - & - & - & - & - & 1 & - & 1 & - & 2 \\
\hline слов. & - & - & - & 1 & - & - & - & - & - & - & - & - & - & - & - & - & - \\
\hline рос. & - & - & 2 & 2 & - & - & - & - & - & - & - & - & - & - & - & - & - \\
\hline біл. & - & - & 1 & - & - & - & - & - & - & - & - & - & 1 & - & - & - & - \\
\hline стсл. & - & - & - & - & - & - & - & - & - & - & - & 5 & - & - & - & - & - \\
\hline цсл. & 1 & 3 & - & - & 1 & - & - & - & - & - & - & 2 & 7 & - & - & 3 & - \\
\hline тюрк. & - & 48 & 2 & 4 & 5 & 2 & - & 3 & - & 6 & - & 8 & 13 & - & 4 & - & 2 \\
\hline тур. & - & - & 5 & - & - & - & - & - & - & 6 & 1 & 3 & - & - & - & - & - \\
\hline тат. & - & - & - & - & - & - & - & - & - & 1 & - & - & - & - & - & - & - \\
\hline осет. & - & - & - & - & - & - & - & - & 1 & - & - & - & - & - & - & - & - \\
\hline ар. & - & - & 4 & - & - & - & - & - & - & 3 & 2 & 5 & - & - & - & - & - \\
\hline перс. & - & 1 & 2 & - & - & - & - & 1 & 1 & - & - & 2 & - & - & - & - & - \\
\hline лат. & 7 & 9 & 1 & - & 1 & 1 & 1 & - & 1 & - & 4 & 23 & 21 & 6 & 6 & 13 & 23 \\
\hline гр. & 4 & 2 & - & - & - & - & - & - & - & 2 & 2 & 15 & 23 & 1 & 3 & - & 3 \\
\hline фр. & - & 6 & 2 & 2 & 2 & 4 & - & 1 & 1 & - & - & 5 & 4 & - & - & - & 1 \\
\hline рум. & - & - & - & - & - & - & - & - & - & - & - & 3 & 2 & - & 1 & - & - \\
\hline ісп. & - & - & - & - & - & - & - & - & - & - & - & 1 & - & - & - & - & - \\
\hline
\end{tabular}

${ }^{9}$ R. Grze gor c zy kow a, Pojęcie językowego obrazu swiata, [w:] Językowy obraz swiata, Lublin 1990, s. 45.

${ }^{10}$ F. Dornseiff, Der deutsche Wortschatz nach Sachgruppen. 1. Aufl, Berlin-Leipzig 19331934, [w:] Ю. Н. К ар ау л о в, Общая и русская идеография, Москва 1976, с. 242.

11 1) назви на позначення психічних та емоційних станів людини; 2) військова лексика; 3) назви тканин, шкіри, хутра; 4) назви взуття та текстильного вбрання, яке одягається на ноги; 5) назви головних уборів; 6) назви на позначення прикрас та оздоблювальних елементів одягу; 7) назви на позначення натільного одягу; 8) поясний одяг та його оздоблювальні елементи; 9) назви на позначення короткого верхнього одягу; 10) назви на позначення верхнього одягу; 11) назви на позначення кольорів; 12) назви харчових продуктів та процесу споживання, приготування та зберігання їжї; 13) назви осіб за професійним спрямуванням чи родом занять; 14) лексика на позначення освітньо-педагогічного процесу; 15) назви одиниць виміру та ваги; 16) нумеральна i темпоральна лексика; 17) лексика на позначення грошових одиниць та операцій з ними. 


\begin{tabular}{|c|c|c|c|c|c|c|c|c|c|c|c|c|c|c|c|c|c|}
\hline іт. & 1 & 12 & 2 & 1 & 1 & 1 & - & - & - & - & 1 & 5 & 4 & - & - & - & 1 \\
\hline нім. & 6 & 36 & 11 & 2 & 1 & 10 & - & 7 & 1 & 2 & 8 & 19 & 47 & - & 18 & 4 & 11 \\
\hline англ. & - & - & 1 & - & - & - & - & - & - & 1 & - & - & - & - & - & - & - \\
\hline уг. & 1 & 5 & - & - & 1 & - & - & - & 1 & 1 & - & 1 & 4 & - & 3 & - & 1 \\
\hline мад. & 3 & - & - & - & - & - & - & - & - & - & - & 1 & 1 & - & - & - & 2 \\
\hline лит. & - & - & - & - & - & - & - & - & - & - & - & 1 & 3 & - & - & - & 1 \\
\hline ісл. & - & - & 1 & - & - & - & - & - & - & - & - & 1 & - & - & - & - & - \\
\hline шв. & - & - & - & - & - & - & - & - & - & - & - & - & - & - & 1 & - & - \\
\hline скан. & - & - & - & - & - & - & - & - & - & - & - & - & - & - & 1 & - & - \\
\hline гот. & - & - & - & - & - & - & - & - & - & - & - & - & 8 & - & - & - & - \\
\hline гол. & - & 3 & - & - & - & 1 & - & - & - & - & 1 & - & 1 & - & - & - & - \\
\hline
\end{tabular}

Для кожної тематичної групи лексики характерна різна наповненість польськими запозиченнями: окремі є досить розгалуженими (назви на позначення психічних та емоційних станів людини - 108 слів; військова лексика 70 слів, назви осіб за професійним спрямуванням чи родом занять - 52 слова), інші - малочисельними (назви на позначення кольорів - 8 слів, назви головних уборів та назви на позначення верхнього одягу — по 5 слів, лексика на позначення освітньо-педагогічного процесу - 1 слово).

Зазначимо, що едиція інтенсивності запозичень із різних мов в окремих пам'ятках також виявила тенденцію домінування полонізмів над іншими запозиченнями. Напр., аналіз лексичного складу Лохвищької ратушної книги другої половини XVII cm. (актів № 1-50) дає змогу робити висновки про перевагу польських запозичень (із 739 запозичень — 365 полонізмів). Жанрова специфіка пам'ятки впливає й на різну інтенсивність уживання окремих запозичень: від поодиноого (пол. найбарзеи, варуємъ, велие, внеть, долегливости, зуполне / зупелне, нецьнотливыи, потваръ, лат. викарии) до багаторазового (пол. ведлугь - 41, жеби - 38, жадным - 21, очевисто - 39, нім. войть - 53, лат. декреть - 31, артикуль - 24, чес. грош - 41). Зауважимо, що більшість полонізмів зафіксовано пам' ятками XVI - XVII ст. ділового й полемічного стилю.

Складною лишається проблема встановлення часу проникнення запозичення в мову-реципієнт. Іноді лінгвістам удається простежити, коли вперше в писемних джерелах досліджуваного періоду зафіксована та чи та лексема. Саме цю дату першої презентації запозичення в українськомовних пам'ятках умовно вважатимемо часом переймання іншомовного елемента в мову-реципієнт, оскільки авторка цієї праці свідома того, що лексема могла існувати в українській уснорозмовній мові чи в пам'ятках, що ще не стали об'єктом едиції й лексикографічного опрацювання, ще задовго до часу написання відповідного твору, або ж ця лексема $\epsilon$,авторським” запозиченням, що вказує на його мовну обізнаність, проте не мала значного поширення, а тому не відбита іншими пам'ятками. Це дає підстави стверджувати, що дата написання твору не завжди може точно відповідати часу проникнення запозичення в мову-реципієнт, а тому $є$ умовною. Ю. Сорокін наголошував, що „запозичене слово $є$ готовим лексичним матеріалом, який міг бути взятий із однієї мови в іншу в різний час. Тільки для тих запозичених слів, для яких зрозуміло, коли вони з'явилися в мові-джерелі, можна 3 повною достовірністю встановити крайню точку, час, раніше якого вони не могли з'явитися в мові, що їх запозичила"12. Зіставлення різних історико-лексикографічних та лексикологічних джерел в опрацюванні іншомовних запозичень часто виявляє розбіжності в питанні трактування часу

12 Ю. Сорокин, Развитие словарного состава русского литературного языка 30-90-е годы ХІХ века, Москва-Ленинград 1965, с. 59-60. 
3'яви запозичень у мові-реципієнті (напр.: лат. акт: ICУМ - 1567 р., ICУЯ 1622 р., МСТ - 1657-1674 рр.; пол. валка: ІСУЯ - 1347 р., ІСУМ - 1489 p., МСТ - 1541 р. і т.д.), що зумовлено різною кількістю опрацьованих різножанрових пам’яток при їх укладанні (порівн.: список опрацьованих джерел до ІСУМ становить 35000, до ІСУЯ - 400, а до МСТ - 34). Проблема хронологізації запозичень лишається актуальною, оскільки прочитання пам'яток саме під цим кутом зору має особливе значення для історії східнослов' янських етносів та їхніх мов, поглиблює розуміння багатопланового у своїх виявах процесу контактування й взаємодії мов.

Не менш складним для з'ясування в кожному конкретному разі залишається питання про шляхи проникнення запозичень у мову-реципієнт: безпосередньо 3 мови-джерела чи через посередництво інших мов і яких саме. Безпосереднє контактування українського та польського етносів сприяло з'яві значної кількості полонізмів у староукраїнських писемних пам'ятках (колвекъ < kołwiek, остатне < ostatnie, очевисто < очевистый < oczewisty, пожекгнати < pożegnać, поневажь < ponieważ, потваръ < potwarz, ведлугъ < wedlug, зуполне < zupełnie, барзо < barzo, звадияа < zwadca, зациный < zacny, долегливость < dolegliwość, звлаща < zwłaszcza, збитєчъний < zbyteczny та ін.). Велику роль відіграла польська мова i в процесі переймання іншомовних елементів як мовапосередниця, зокрема із 618 проаналізованих запозичень (полонізми не враховані) через посередництво польської мови в староукраїнську було перейнято 157 лексем, серед яких переважають германізми та латинізми ${ }^{13}$ (див.: Табл. 2).

Таблиця 2.

\begin{tabular}{|c|c|}
\hline $\begin{array}{c}\text { Мова-джерело } \\
\text { запозичення }\end{array}$ & $\begin{array}{c}\text { Лексеми, що запозичені в староукраїнську мову } \\
\text { через посередництво польської мови }\end{array}$ \\
\hline Hiм. (77) & 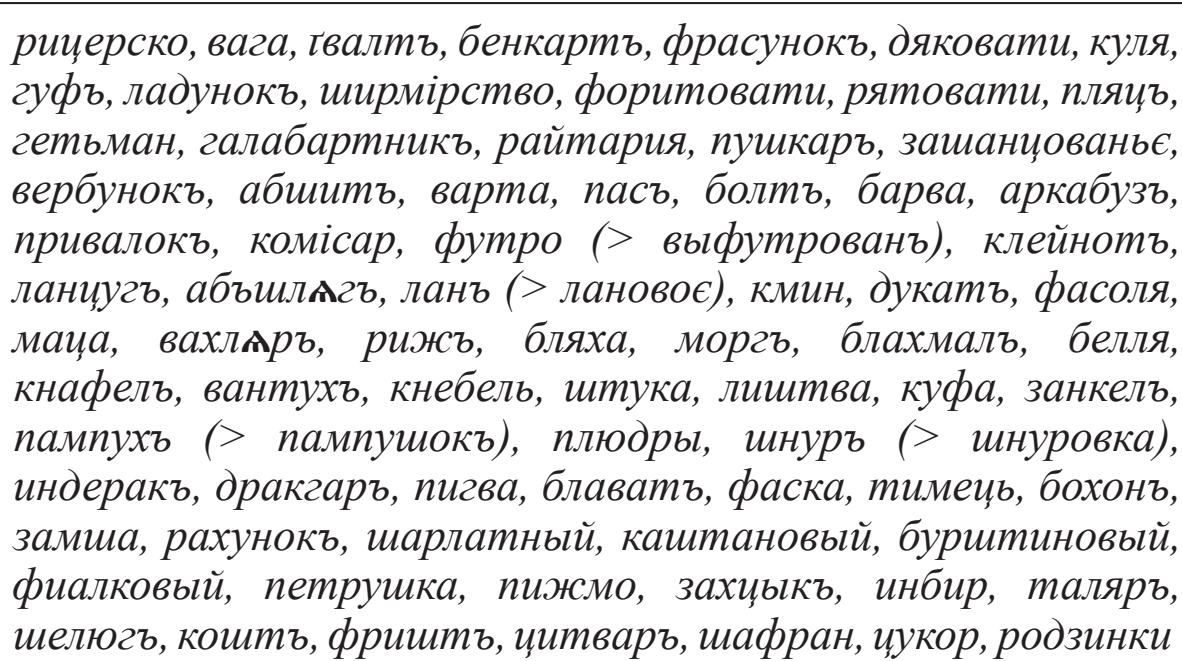 \\
\hline лат. (34) & $\begin{array}{l}\text { лементька, анімушъ, виоленция, ветовати, дигнитарство, } \\
\text { левизоръ, венеровати, афектъ, лекція, академія (< гр.), } \\
\text { інспектор, семінарій, алюмн, чиншъ, квота, гимнастес } \\
\text { (<гр.), префект, гармата, аппаратъ, експедиция, здезеловати, } \\
\text { компанія (> компанійци), дукля, аквавита, курта, кораль (> } \\
\text { коралньй), буряк (> бураковьй), карбунколовьй, кардимонъ, } \\
\text { цчнамонъ, корїандеръ, цитрина, булка, миля }\end{array}$ \\
\hline
\end{tabular}

13515 латинізмів, запозичених за посередництва польської мови, стали предметом окремої едиції в монографії: С. Гриценко, Лексичні латинізми в украӥнськомовних текстах кіния XVI - ХVII століття, Київ 2011, с. 112-132. 


\begin{tabular}{|c|c|}
\hline iT. (15) & $\begin{array}{l}\text { кавалеръ, мушкетъ, дарда, гвардия, белюарда, кгаляра, } \\
\text { шпада, манеля, буратикъ, шкарпетка, помаранча (> } \\
\text { помаранчовий), салат, гармашъ, кавалкаторь, дукать }\end{array}$ \\
\hline фp. (13) & 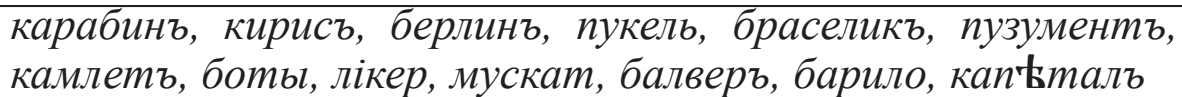 \\
\hline анг. (1) & каразь \\
\hline уг. (2) & катанка, трембачъ \\
\hline рум. (1) & домна \\
\hline слов. (1) & капц̧и \\
\hline гр. (1) & дактиль \\
\hline чес. (1) & кyxapb \\
\hline тюрк. (2) & кончерь, папуиьь \\
\hline тур. (5) & делия, делюра, кобзистый, кунътушъ, атласъ \\
\hline перс. (1) & кабать \\
\hline ap. (3) & жсупанъ, кармазинь (> кармазиновый), лазуровий \\
\hline
\end{tabular}

Іноді важко однозначно вказати, яка саме мова виступала у функції посередниці в процесі переймання запозичень, зокрема укр. гоноръ, гонеръ < стп. чи стч. honor < лат. honor.

Дискусії серед етимологів часто викликають не лише мови-посередниці, а й саме джерело запозичення, зокрема укр. каптуръ (> капътуровый) трактується як чеське запозичення (стч. kaptour ${ }^{14}$, стч. kaptúr ${ }^{15}$ ) О. Буликою ${ }^{16}$, як польське запозичення (стп. kaptur) Є. Тимченком ${ }^{17}$, як італійське (іт. capparo, capero) Е. Бернекером ${ }^{18}$, О. Преображенським ${ }^{19}$, О. Соболевським ${ }^{20}$, як латинське запозичення (лат. captura $<$ нар.лат. сарра) Ф. Славським ${ }^{21}$, як тюркське запозичення (чаг. kaptur) Ф. Міклошичем ${ }^{22}$, укладачами Етимологічного словника української мови ${ }^{23}$ та Словника української мови XVI-nершої половини XVII cm. ${ }^{24}$. Не визначилися етимологи й щодо мови-посередниці в процесі переймання цього запозичення: безпосередньо з тюркських, польської чи чеської мов чи через посередництво польської чи чеської мов з італійської, латинської чи тюркських мов.

Окреслення шляху запозичення завжди залишає місце для дискусій і уточнень, оскільки вияв нових джерел може змінити оцінки щодо наявності й характеру посередництва при перейманні конкретної мовної одиниці.

${ }^{14}$ Stownik wyrazów obcych, wyd. 9, red. Z. Ry s i e w i c z, Warszawa 1963, s. 324.

${ }^{15} \mathrm{~J}$. Karło w i c z, Słownik wyrazów obcego a mniej jasnego pochodzenia: używanych w języku polskim, Kraków 1894-1905, s. 252.

${ }^{16}$ А. М. Бул ы к а, Лексічныя запазычанні у беларускай мове XIV-XVIII ст., Мінск 1980, с. 112.

${ }^{17} \mathcal{C}$. К. Т и м ч е н ко, Матеріали до словника писемноїта книжноїукраӥнськоїмови XV-XVIII cm., Київ, Нью-Йорк 2002, кн. 1, с. 357.

${ }^{18}$ E. B er n e k e r, Slavisches etymologisches Wörterbuch, Heidelberg 1924, t. 1, s. 487.

${ }^{19}$ А. Г. Пр е об р а же н ск и й , Этимологический словарь русского языка в 4 m., Москва 1958, т. 1 , c. 294.

${ }^{20}$ А. И. Соболев ськи й, Изъ исторіи русскаго словарнаго матеріала. По поводу новыхъ выпусковъ этимологическихъ словарей Э. Бернекера и А. Г. Преображенскаго, [в:] „Русскій филологическій в встниикъ, Warszawa 1913, т. LXX, № 3, s. 85.

${ }^{21}$ F. S ła w s ki, Stownik etymologiczny języka polskiego, Kraków 1982, т. 2, s. 61.

${ }^{22}$ F. Miklosich, Die türkischen Elemente in den südost- und osteuropäischen Sprachen, Nachtrag-Wien 1890, t. II, s. 142.

${ }^{23}$ Етимологічний словник украӥнської мови в $7 \mathrm{~m}$., редкол. О. С. Мельничук, Київ 1985, т. 2, с. 377 - далі ЕСУМ.

${ }^{24}$ Сл о в н и к української мови XVI- першої половини XVII cm., Львів 2008, вип. 14, с. 46. 
Важливим аспектом у дослідженні лексичних запозичень $є$ аналіз супровідних та подальших семантичних змін, оскільки ,доля запозичених слів залежить <..> від процесу семантичного пристосування, від того, наскільки ïх введення виправдано потребою вираження особливих понять, нових значень і смислових відтінків"25. Зауважимо, що запозичення, пристосовуючись до фонетичної й морфологічної систем мови-реципієнта, підпорядковуються нормам цих систем; вони не можуть порушити стійкості цих рівнів мови. На семантичному рівні відбуваються зміни іншого порядку: пристосовуючись до іншої лексико-семантичної системи, запозичення зазнають впливу цієї системи, але й сама семантична система мови-реципієнта зазнає змін під впливом цього запозичення. У процесі тлумачення семантичних змін запозичення дослідник часто послуговується даними лексикографічних джерел, що можуть різнитися підходами їхніх авторів в оцінці значень одних і тих самих лексем. У цьому контексті пригадуємо слова Е. Бенвеніста: „Критерії формальної реконструкції <..> можуть бути дуже строгими, оскільки вони визначаються точними правилами $<\ldots .>$. Що ж стосується сфери значення, то єдиним дороговказом є певна правдоподібність, що базується на „здоровому глузді”, особистій думці лінгвіста і тих паралелях, які він зможе навести"26.

Едиція польських запозичень, зафіксованих у староукраїнських писемних джерелах XVI - XVII ст., дає змогу окреслити такі моделі семантичної адаптації до системи мови-реципієнта та подальшого функціонування в сучасній українській мові: 1) запозичення з часом зникає 3 мови-реципієнта разом із відповідною реалією. Зауважимо, що „процес входження і процес зникнення застарілих слів із мови - це процеси різного ступеня інтенсивності. Процес зникнення слів $<\ldots>$ довготриваліший, порівняно $з$ процесом засвоєння нових слів <..> Процесу виходу слів з ужитку <..> передує їх постійне „старіння”, звуження їх слововжитку <..> і зміна їхнього значення та стилістичної характеристики"27. Напр.: полонізм колтрышъ „грубе, просте сукно” (> колтрышокъ, колтрышиовый, колтрышский < стп. kołtrysz „сукно простого виготовлення" (kołtryszek) ${ }^{28}$ ) часто фіксується староукраїнськими пам'ятками, має ряд похідних, однак на сучасному етапі розвитку української мови ця лексема не вживається, оскільки реалія, яку вона номінує, не є ужитковою; 2) запозичення староукраїнського періоду продовжує своє функціонування в сучасній українській мові зі сталою семою. Напр.: полонізм жебракъ ,людина, яка живе 3 милостині; старець; дуже бідна людина" (< стп. żebrak ${ }^{29}<$ жебрати $<$ стп. żebrać < чес. žebrati < стч. škebrati „канючити”зо) 3 цим же значення вживається в сучасній українській мові ${ }^{31}$; 3) запозичення активно функціонують у староукраїнський період, а в сучасній українській мові замінюються синонімом. Напр.: у староукраїнський період для номінації поняття „цукор” використовува-

${ }^{25}$ Ю. А. С ороки н, указ. источник, с. 64.

${ }^{26}$ E. B e nve niste, Problémes sémantiques de la reconstruction, [w:] Word, New York 1954, v. 10 , № 3-4, s. 251 .

${ }^{27}$ Ю. А. С ор о ки н , указ. источник, с. 11.

${ }^{28}$ Словник украӥнської мови XVI ..., вип. 14, с. 199; ECУМ, т. 2, с. 525; Słownik języka polskiego, ułozony pod red. J. Karłowicza, A. Kryńskiego, W. Niedżwiedzkiego, Warszawa $1900-1927$, t. 2 , s. 413.

${ }^{29}$ Словник украӥнської мови ХVI... , вип. 9, с. 134.

${ }^{30}$ ЕСУМ, т. 2, с. 191; A. B rü c kn e r, Stownik etymologiczny języka polskiego, Warszawa 1957, s. 663; V. M a c he k, Etymologický slovnik jazyka českèho a slovenskèho, Praha 1957, s. 611.

${ }^{31}$ Сл ов ник украӥнської мови, за ред. І. К. Білодіда, в 11 т. Київ 1971, т. 2, с. 517 - далі СУМ. 
лися полонізм фарина (< пол. faryna „неочищений цукровий пісок”32), грецизм

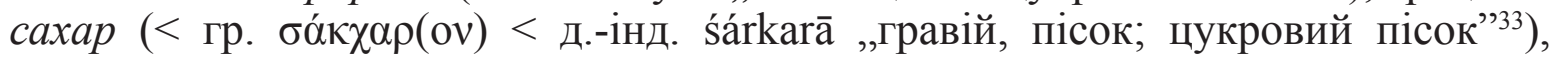
германізм иукор (< через пол. посередництво (cukier) $<3$ нім. Zucker $<$ італ. zucchero < лат. succarum < д.-інд. śárkarā $\left.{ }^{34}\right)$. На сучасному етапі розвитку української мови полонізм фарина був витіснений у розмовному мовленні грецизмом сахар, що має низку похідних (сахарещъ, сахарин, сахариновий, сахаристий, сахаристість, сахарити, сахарний, сахарниия, сахарня, сахаровар, сахароваріння, сахароварний, сахароза, сахарозаводчик ${ }^{35}$ ), а нормативним став германізм иукор з рядом похідних: иукорниця, иукорничка, иукорня, иукорок, иукринка, иукристий, иукристість, иукробуряковий, иукрований, иукровар, иукроваріння, иукроварний, иукроварня, иукровий, иукровик, иукровичка, иукровість, иукряний, иукроза, иукрозавод, иукрозаводський, иукрозаводчик, иукрозаводчиия, иукрозний, иукрокомбінат, иукрофінадний, иукросировина, иукротрест, иукрування ${ }^{36}$. Велика кількість дериватів цих запозичень у сучасній українській мові зумовлена активним розвитком цукрового виробництва в Україні упродовж XVI - XXI ст.; 4) запозичення староукраїнського періоду в діахронічній проекції зникає з літературної мови, однак продовжує функціонувати в окремих діалектах. Напр.: лексема шарый „сірий, темно-сірий” (< пол. scary $^{37}$ ) активно функціонувала в староукраїнський період, позначаючи відповідне забарвлення тканини, одягу, а також масть коней. Зауважимо, що цей полонізм зафіксований також у сполуці шара риба, що номінує страву, приправлену соусом сірого кольору ${ }^{38}$. У сучасній українській літературній мові ця лексема не вживається, однак фіксується в діалектах на позначення „сірого” кольору ${ }^{39}$; 5) запозичення активно використовується мовцями в староукраїнський період розвитку мови, а з часом у літературній мові набуває маркування застарілої лексеми або кваліфікується як історизм. Напр.: полонізм опричникъ „розбійник, грабіжник”40 (< пол. opryszek ,розбійник, бандит, злодій”41) був частовживаним у пам'ятках досліджуваного періоду, а в сучасній українській мові це слово $\epsilon$ історизмом і позначає „дворянина, який служив в оприччині”"42; 6) моносемантичне запозичення продовжує активне функціонування в літературній мові в діахронії, а в діалектному мовленні „обростає” новими значеннями, похідними. Напр.: префіксально-суфіксальне утворення запаска, що походить від полонізму pas „пояс"43, у староукраїнський період (XVII ст.) позначало „жіночий одяг у вигляді шматка тканини (переважно вовняної) певного розміру, що використовувався замість спідниці для обгортання стану поверх сорочки, запаска”, „по-

${ }^{32}$ Польсько-украйнський словник в 2 m, за ред. Л. Л. Гумецькоӥ, Київ 1960, т. 2, с. 243.

${ }^{33}$ ЕСУМ, т. 5, с. 191; М. Ф а с м е р, Этииологический словарь русского языка в 4 т., Москва 1971, т. 3, c. 567.

${ }^{34}$ ECУM, т. 6, c. 265.

${ }^{35}$ CУM, т. 9, c. 62.

${ }^{36}$ Там с амо, т. 11, с. $246-248$.

${ }^{37}$ Матер іали до словника писемної та книжної украӥнської мови XV - XVIII ст., КиївНью-Йорк, 2003, кн. 2, с. 489; ЕСУM, т. 6, с. 382; A. B rü ckn e r, op. cit., s. 541; V. M a ch e k, op. cit., s. 605-606.

${ }^{38}$ S. Li inde, Stownik języka polskiego, Lwów 1859, t. 5, s. 555; Słownik języka polskiego..., t. 6 , s. 571.

${ }^{39} \mathrm{CУM}$, т. 11, c. 412.

${ }^{40}$ Матері іал и до словника..., кн. 2, с. 49.

${ }^{41} E C У M$, т. 4, c. 204; A. B rü ckn e r, op. cit., s. 437.

${ }^{42}$ СУM, т. 5, c. 729.

${ }^{43}$ ECУM, т. 4, c. 303; A. B rü ckner, op. cit, s. 398. 
лотнище з зав'язками, яке носили спереду поверх плахти"44. Синонімом до лексеми запаска в пам'ятках XVI - XVII ст. було слово запасница та рідкісна українська інновація запояска, а пам'ятки XVIII ст. фіксують паралельне вживання лексем запаска й запояска (остання не збережена сучасною українською літературною мовою, а фіксується лише Малоруско-німецьким словарем С. Желехівського і С. Недільського ${ }^{45}$ ), і вже наприкінці XIX ст. запаскою почали називати звичайний фартух із фабричної тканини, який одягали поверх спідниці або плахти ${ }^{46}$. Лексема запаска донині зберегла основне значення, а в діалектах розширила своє семантичне значення новими, зокрема „фартух" "47, „пояс"48, „чоловічий пояс"49, „сорочка”, „тканина (зайва, запасна)” ${ }^{50}$. Основна діалектна сема „фартух" у бойківських говірках передається ще синонімами запинка, запаща, припинка ${ }^{51}$, а в середньополіських та суміжних говірках - запинало, запинач, запинка, запинанка, запиначка ${ }^{52}$, в гуцульському говорі - словосполученням поверхна запаска ${ }^{53}$.

Зазначимо, що кожна семантична модель по-різному представлена у відповідних тематичних групах лексики, що обумовлено позамовними чинниками розвитку мови, семантичною специфікою самої групи.

Типовим явищем, що супроводжує процес запозичення, є з'ява семантичних дублетів у мові-реципієнті. Досліджуючи польські запозичення, зафіксовані в староукраїнській мові XVI - XVII ст., виявлено семантичні дублети практично у всіх тематичних групах лексики (поняття „обман, брехня” номінувалося питомими лексемами: баламутство, баламутня, бреханє, лганьє, лож та запозиченнями: кламство (пол.), кламана (пол.), змышиланьє (пол.), ошуканє (пол.), облудность (пол.) — бенкарть (нім.) — фалшь (лат.); ця тенденція простежується й у військовій лексиці: моцованіе (пол.), валка (пол.), утарчка (пол.), потычка (пол.), бедженє (пол.) - ширмерство (нім.), гариъ (нім.) - потреба (укр.), росправа (укр.), бой (укр.), бойка (укр.), битва (укр.)).

Едиція польських лексичних запозичень, зафіксованих староукраїнськими писемними пам'ятками, переконує в істинності твердження Ю. Сорокіна про те, що „кожен стан лексичного складу є лише момент у безперервному ланцюгу його змін. У кожному такому історичному моменті відображені попередні

${ }^{44}$ Словник украӥнської мови ХVI ..., вип. 10, с. 131.

${ }^{45}$ С. Же л ех і в с ь к й , С. Н еді ль с ь к й , Малоруско-німец̧кий словар в 2 m., Львів 1886 , T. I, c. 264.

${ }^{46}$ CУM, т. 3, с. 247.

47 П. П. Білецький-Н с енно, Словник украӥнської мови в 2 m., Київ 1966, с. 146; I. В е рх ратський, Говір батюків, [в:] ЗНТШ, Львів 1912, т. 15, с. 267; Ф. И. Ба бий, Бblтовая лексика говоров среднего бассейна Горыни (названия одежды, обуви и головных уборов), Дис. канд. філол. наук, Ужгород 1985, с. 72, 75; Мате рі али до словника буковинських говірок в 2 m., Чернівці 1979, т. II, с. 29; Г. П. А ркуш и н, Словник західнополіських говірок, Луцьк 2000, т. I, с. 172; А. С. С о ко ло в с кая, Полесские названия одежды и обуви, [в:] Лексика Полесья, Москва 1968, с. 288; Г. Гр и м аш е в и , Словник назв одягу та взуття середньополіських та суміжних говірок, Житомир 2002, с. 53; Г. Бе ре з о с ь ка, Словник назв одягу та взуття у східно-подільських говірках, Умань 2010, с. 84-85.

48 Б. Кобилянський, Гуиульський говір $i$ його відношення до говорів Покуття, [в:] Український діалектологічний збірник, Київ 1928, кн. 1, с. 70; Г. Гр и ма ш е в и ч, зазн. джерело, с. $53 ;$ Г. Бе ре з о в с ь ка, зазн. джерело, с. 84-85.

${ }^{49}$ Г. Гр и маш е в и ч, зазн. джерело, с. 53.

${ }^{50}$ Г. Бе ре зо в с ь ка, зазн. джерело, с. 84-85.

${ }^{51}$ М. Й. О н и ш ке в и ч, Словник бойківських говірокв 2 m., Київ 1984, т. I, с. 279.

${ }^{52}$ Г. Гр и маше в ич, зазн. джерело, с. 54.

53 Картотека Словника гуиульських говірок, зберігається в Інституті українознавства ім. І. Крип’якевича НАН України у Львові. 
зміни, нашарування різних епох і стимули подальших змін" ${ }^{54}$. Лексичні запозичення є своєрідними міні-історіями формування української МКС, адже, як зауважив італійський дослідник А. Грамші, ,історія семантики - це аспект історії культури: мова становить одночасно і щось живе і музей старожитностей життя та цивілізацій"

Лише комплексне вивчення запозиченої лексики вможливить уточнення даних щодо часу, шляхів, мети, значення запозичення, процесу його адаптації та подальшої трансформації тощо. У цьому контексті видається необхідним створення словника лексичних запозичень, що базувався би на найновіших дослідженнях різножанрових і різночасових пам'яток та на найповніших сучасних картотеках історичних словників слов’янських мов.

${ }^{54}$ Ю. А. С о р о к и н, указ. источник, с. 20.

${ }^{55}$ A. G r a m s c i, Il materialismo storico e la filosofia di Benedetto Crose, Torino 1948, s. 146. 